\title{
Beekeeping in late medieval Europe: A survey of its ecological settings and social impacts
}

\author{
La apicultura en la Europa medieval tardía: un estudio de su entorno \\ ecológico y sus impactos sociales
}

Lluís SALES I FaVÀ, Alexandra SAPOZNIK y Mark Whelan

Authors:

Lluís Sales i Favà

Department of History

King's College London (England)

sales.fava.lluis@gmail.com

http://orcid.org/0000-0002-0824-0135

Alexandra Sapoznik

Department of History

King's College London

alexandra.sapoznik@kcl.ac.uk

Mark Whelan

Department of History

King's College London

mark.whelan@kcl.ac.uk

http://orcid.org/0000-0002-2234-5419

Date of reception: 14/04/21

Date of acceptance: 30/07/21

Citation:

Sales i Favà, Ll.; Sapoznik, A.; Whelan, M. (2021). Beekeeping in late medieval Europe: A survey of its ecological settings and social impacts. Anales de la Universidad de Alicante. Historia Medieval, (22), 275-296. https://doi.org/10.14198/medieval.19671

Funding: Leverhulme Trust RPG-080-2018 'Bees in the Medieval World: Economic, environmental and cultural perspectives'

(C) 2021 Lluís Sales i Favà, Alexandra Sapoznik y Mark Whelan

Licence: This work is licensed under a Creative Commons Attribution 4.0 International License (CC BY 4.0).

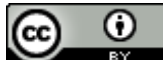

\begin{abstract}
In the middle ages bees held significant economic, social and cultural importance. Constant demand for wax was driven by Christian religious practice among many other uses, while honey provided the only widely accessible sweetener in an era before large-scale sugar imports. Consequently, beekeeping was a notable part of the rural economy, drawing on the participation of numerous groups across Europe, from peasants with only a few hives for small-scale production to specialized beekeepers producing for a thriving international trade. Analysis of a wide variety of documents from northern and southern Europe, shows the importance of beekeeping in the late medieval period, and the ways in which different environments and types of economic and social organization consequently gave rise to different forms of beekeeping. This paper demonstrates that beekeeping was not an isolated activity, but rather one which competed and conflicted with, and conflicted with, many other types of resource use from a variety of actors. As such, beekeeping provides a lens through which to consider human intervention in the natural environment, demonstrating the extent to which the medieval landscape was regulated, managed, mediated and anthropized.

KEYWORDS: apiculture; beekeeping; bees; ecology; environment; wax; honey.
\end{abstract}




\section{INTRODUCTION}

In the middle ages bees held significant economic, social and cultural importance. ${ }^{1}$ Constant demand for wax was driven by Christian religious practice, in addition to its use for seals, writing tablets, casting, and luxury lighting, while honey provided the only widely accessible sweetener in an era before large-scale sugar imports. Consequently, beekeeping was a notable part of the rural economy, drawing on the participation of numerous groups across Europe, from peasant producers with a few hives intended for local consumption to specialized beekeepers engaged in largescale production for a thriving international trade. A wide variety of documents demonstrate that beekeeping took place within many ecological contexts, and the regions discussed in this study have been chosen for their well-documented apiculture in diverse settings. For northern Europe two areas in particular will be discussed: the region of Prussia and Livonia, which stretched along the coasts of the Baltic Sea and into its heavily forested hinterland, and Franconia around the Imperial Free City of Nuremberg, in the modern German state of Bavaria. In the south, the regions of the Alentejo and Beira Interior in Portugal, parts of the Kingdom of Valencia, the Principality of Catalonia and the county of Provence will be especially considered. Together, these places represent different environments and types of economic and social organization, which consequently gave rise to different forms of beekeeping.

Hive types across Europe were adapted to particular environments, determined by landscape, vegetation, precipitation and temperature. Broadly, northern Europe may be divided into two regions: that of tree beekeeping, in the area to the east of the Elbe river in eastern Germany in a broad swathe extending south through Bavaria and east through Poland to the Ural Mountains; and that of skep beekeeping to the west and south of this zone (Crane, 1999, p. 128). In the former region, heavily forested and thinly settled, bee forests were created through hollowing out large spaces in tree trunks and allowing bees to naturally move from tree to tree as they swarmed, protected from the worst of the winter weather within the trees' cavities. This is a form of wild honeyhunting and beekeeping, although within a highly managed environment, in which cutting down or damaging certain trees and removing forest litter or other resources was forbidden or strictly contained through a legal rights, privileges and customs (Losert and Werther, 2010, p. 218; Warnke, 1987 , p. 555). It is the rights over these woodland resources and the problems which arose from overlapping uses and claims to them which generated the records that allow for a clear picture of Prussian and Livonian beekeeping in lands held by the Teutonic Order, and in Nuremberg, where imperial rights over forests were also well-defined. Franconia lay on the border of an intermediary zone in which log hives

1 The research for this paper was undertaken as part of the project 'Bees in the Medieval World: Economic, environmental and cultural perspectives', funded by the Leverhulme Trust (RPG-080-2018). 
were used, either as the dominant hive type or alongside tree beekeeping. Such landextensive forest beekeeping was possible on a large scale through a confluence of factors. Limited population, even in this period of settlement expansion, meant that arable fields had not entirely encroached into the forests. Since most arable crops do not provide bee forage, the expansion of arable across Europe over the high middle ages was in many places detrimental to bee habitats. But the forests in which largescale productive beekeeping took place also combined particular tree types. By and large, they were deciduous forests with stands of conifers such as pine and larch, a mix which produced abundant honeydew and where the tree canopy was not so dense as to prevent the low-level shrub and flower growth necessary bee for forage. (Warnke, 1987, pp. 552-55)

To the south of this region, log hives gave way to a variety of skeps and other containers. In the Mediterranean and Iberia, much beekeeping took place in cork hives which were light and easy to move while also protecting bees from the heat of summer (de Crescenzi, 1474, "De alvearis"; Alonso de Herrera, 1546, f. 142r; Agustí, 1617, f. 184v; Gil, 1621, f. 13r; Carmona Ruiz, 1999, p. 394). This zone encompassed many different landscapes, from the highly managed montadodehesa system of agro-silvo-pastoral husbandry which combined grass grazing with arboriculture-especially of cork oak - to the deforested, bee-abundant maquis and garrigue with blooms of cistus, asphodel and rosemary, to interspersed pine forests at higher altitudes. Frequent burning of shrubland by pastoralists for grazing constantly renewed bee forage in many places, while more forested areas provided different patterns of floration and honeydew. For this reason, transhumant beekeeping, in which hives were moved between summer and winter foraging areas was a particular feature of some parts of this region (Lemeunier, 2004).

Within the areas under study here, some places, such as Valencia and Andalusia, were comparatively highly populated, and the prevalence of arable agriculture and viticulture meant that beekeeping was highly regulated to keep beehives away from settlements and vineyards, and from each other due to competition for forage (Ortega Gil, 1995, pp. 51-2; Sánchez Benito, 1989; Martín Gutiérrez, 2011). Overall, however, so conducive was this region to beekeeping, with its warm weather, mild winters and abundance of flowering plants and bee forage, that honey was harvested multiple times a year (Canova, 1999, p. 22). The specific environments of this complex zone will be discussed in more detail below, and, as in the north, it will be seen how these intersected with social organization, claims to resources, and the often-contested purposes to which these resources were put. Throughout, the effects of two forms of settlement expansion will also be seen: on the one hand, that of Christianity through crusade and colonization, which displaced, disrupted and converted the native peoples of the Baltic and the Muslims of the Mediterranean and Iberia; and a general trend of population growth which had begun around the 
turn of the millennium on the other (Pluskowski, 2019b, pp. 1-2, 9-11). Indeed, it should be noted that in most, if not all, of the regions under study here, apiculture is recorded precisely because it came into conflict with other activities in a time of resource pressure or as new territorial lords imposed their own legal structures over already existing societies. In this way, beekeeping provides a lens through which to consider human intervention in the natural environment, demonstrating the extent to which the medieval landscape was regulated, managed, mediated and anthropized. $^{2}$

\section{ECOLOGICAL CONTEXTS}

On the surface, pre-modern beekeeping may appear to have been a low-input activity in which bees flourished on naturally occurring vegetation. In reality, however, the landscapes in which bees were most productive were very much altered to suit the needs of a variety of different human-driven purposes, and across Europe beekeeping was found in complex systems, often competing with extractive activities and animal and cereal husbandry. ${ }^{3}$ Accidental destruction of beehives during the periodic queimadas (fires) in the montado territories of Portugal are indicative of such overlapping uses. Here, cork oaks and olive trees-cultivated for their own saleable commodities-were interspersed with grass and low-lying shrub for grazing livestock, which was renewed through burning. Unsurprisingly, these fires, which were also set to make the charcoal necessary for iron-mongering and fuel, could also result in the burning of hives if they had not been removed beforehand. ${ }^{4}$ These hives were often placed in these areas precisely because of the flowering forage for which such frequent burnings made room. In regions of intensive beekeeping, preference for certain shrubs and trees to ensure year-around and abundant forage could also alter the plantscape. The highly prized honey from pure rosemary, which flowered early in the year, required areas of land in which this plant was dominant, while late-flowering oregano and borage kept honey production up through later harvests, and trees considered bee-friendly, such as pine, cedar, oak, wild olive and almond-

2 As such, the focus here is on forms of beekeeping and the production of wax and honey, and the trade in these products lies outside the scope of this article.

3 For maps of the regions mentioned in this study, readers are pointed to Pluskowski, 2019b, 1-3 (for the Baltic and Central Europe); Bischoff, 1956, 72 (for Franconia); Devy-Vareta, 1985, p. 23 (for Portugal); Riera, 2017, p. 239 (for Valencia and Catalonia) and Boudinot, 2010-2011, p. 48-49 (for Provence).

4 See ANTT (Archivo Nacional Torre do Tombo), Chancelaria de D. Alfonso V, Liv. 34, f. 187 (8-XII-1450); Liv. 3, f. 81 (22-V-1453); Liv. 13, f.108v (11-VI-1456); Liv. 9, f.102-102v (1-VII-1463) quoted by Duarte, 1999, 302; Liv. 29, f. 85 (27-VII-1472); Liv. 30, f. 99r (1-IV-1475); Liv. 30, f. 69r (29-VI-1475); Liv. 32, f.158r (27-V-1480). See also Devy-Vareta, 1985, p. 15. About conflicts for burning hives, see Hinojosa Montalvo, 2020, p. 12. For the relation between swidden agriculture and beekeeping in Provence, see Burri, 2016, p. 57, and in Lleida in the early seventeenth century, Ganau, 1996, p. 54-55. 
the latter of which requires cross-pollination-were preferred over others, such as poplar and elder (Alonso de Herrera, 1546, f. 140v).

In the opposite direction, in the mid-fifteenth century the Dean of Riga and the Teutonic Order reached an agreement in which rights to collect firewood and timber were given in woodland which was unsuited to either tree beekeeping or arable agriculture (Pluskowski, 2019a, p. 555). In this region the beliefs of the formerly pagan peoples, with their sacred forests, rivers, and trees-chief among which was the linden-had a long-lasting effect on the ability of the Teutonic Order to fully exercise their extractive privileges, especially with regard to their ability to tax the produce of already-existing bee trees. The desire of the largely German-speaking newcomers in Livonia to exploit these bee trees created tensions with native Livs in the vicinity of Riga as early as the 1210s, and disputes over who could extract honey and wax from the city's hinterland continued into the later medieval period (Kḷaviňs, 2019, p. 204). In 1349 the Master of Livonia ruled that the trees in a certain area along the river Duna belonged to the Livonians of the settlement of Kirchholm, with the provision that one of third of the honey and the wax from the bees should be given to the city of Riga (von Bunge, 1968, pp. 134-5). The importance attached to the bee produce is underlined by the stipulation that the Livonians were not to ascend the trees and harvest the honey unless a representative of the city was present, lest the latter be cheated out of any portion of their due. This association of beekeeping with people who were increasingly under Christian rule is reflected within an Iberian context in the efforts of the Kings of Portgual and the Crown of Aragon to tax, through different forms of the azaqui tithe, the honey and wax produced in the hives owned by Muslim communities. At least twenty of the foundation charters and privileges granted to Muslim communities in Valencia included some kind of regulation of beekeeping and, namely, seigneurial exactions on hives. ${ }^{5}$ One early case is the 1285 charter granted to the Muslim communities

5 By chronological order see the cases of Xivert: 28-IV-1234, published in Febrer Romaguera, 1991, p. 1016 and also García García, 1948; Vall d'Uixó: Arxiu del Regne de València (ARV), Real Cancelleria, 611, f. 229v-230r (VIII-1250), published in Guinot Rodríguez, 1991, p. 224-226; Bunyol: Arxiu de la Corona d'Aragó (ACA), Reial Cancelleria, reg. 382, f. 46v-47r (VI-1254), published in Guinot Rodríguez, 1991, p. 265-266; Tales: Archivo Histórico Nacional (AHN), OO.MM, Montesa, n. 542, C, f. 49r (13-V-1256), published in Gual Camarena, 1989; Xelva: 7-II-1270, published in Guinot Rodríguez, 1991, p. 582-586; Alfondeguilla and Castro: ARV, Real Cancelleria, 611, f. 218v (7-IV-1277), published in Febrer Romaguera, 1991, p. 116-119 and Guinot Rodríguez, 1991, p. 363-364; Xestalgar: Biblioteca de Catalunya (BC), ms. 2067, f. 15v-17v (27-XII-1284), published in Pastor i Madalena, 2004, p. 101-106; Perputxent: AHN, OO. MM, Montesa, Carp. 520, n. 436-P (1285), published in Febrer Romaguera, 1991, p. 148-151 and subsequently, AHN, OO.MM, Montesa, Lib. 542c, f. 19v-20v (13-VI-1316), quoted by Guinot Rodríguez, 1986, p. 115; Aiora: ACA, Reial Cancelleria, reg. 476, f. 154r-158r (3-VIII-1328), published in Ferrer i Mallol, 1986 and in Febrer Romaguera, 1991, p. 495-501; the Castle of Pop: AHN, Nobleza, Parcent, C.47, D.12 (8-XII-1341), quoted by Cabezuelo, 2019; Xest: ARV, Governació, L. 2,981 M. 13, f. 8r-12r (10-I1371), published in Villalmanzo Cameno, 1986, p. 143-149; Sot de Ferrer: Arxiu Municipal de Sogorb (AMS), Conde de Luna, 215 (1394), quoted by Aparici Martí, 1998, p. 36; the valleys of Gallinera and 
of the valley of Perputxent, which included a modest annual tax of $2 \mathrm{~d}$. for each hive. ${ }^{6}$ This would become a general model in Valencia in income taxation both for Muslim and Christian communities. But of all the rural banalités (mills, forges, butcher shops, barber shops, taverns) and taxes on production that were managed by territorial lords in the Kingdom of Valencia, those related to wax and honey appear to be the least profitable (Guinot, 1992). In the early fifteenth-century Moorish community of Benaguasil, the mill used for processing the wax provided only a small revenue, accounting for $0.16 \%$ of all the royal rents (Aparisi Romero, 2021, p. 125-126). Still, the particular attention paid to ensuring revenue in cash or kind from apiculture by territorial lords both north and south is indicative both of the longstanding prominence of this activity in these regions and the desirability of these products.

\section{APICULTURE AND HIVES}

Despite its economic and ecological importance, there are currently no studies of monograph length focused on medieval beekeeping. Still, its existence is well assessed through documentary evidence from a variety of records, including charters, estate accounts, law codes, notarial registers and treatises. These demonstrate the ubiquity and flexibility of beekeeping across the regions studied, and the wide variety of forms beekeeping could take, according to environmental condition, legal custom, and proximity to urban settlements and other types of land use. In some settlements and estates, hives were concentrated in a particular location for ease of management and security. In 1434, for example, an apperio (apiary) hosted at least 60 hives in the territory of Brinhòla, in Provence. ${ }^{7}$ This enclosure helped protect the bees from predators, livestock, wildfires and burglars, and later examples for the region suggest that these apiaries were enclosed by a stone wall and an outer perimeter for

Ebo: 1397, quoted by Hinojosa Montalvo, 2008-2010; Sumacàrcer: Arxiu Comtal d'Orgaz (ACO), Fons Crespí Valldaura, Ll. B-12, Perg. 51 (23-III-1403), published in Guinot Rodríguez, 1991, p. 637-641; Ribesalbes: ARV, Justícia Civil, L. 809, mà 1, f. 48v-61r (7-III-1405), published in Guinot Rodríguez, 1991, p. 650-656; Ondara: ARV, Mestre Racional, reg. 9,618 (1416), quoted by Hinojosa Montalvo, 2008-2010; Picassent: 1466, quoted by Febrer Romaguera, 1988; Benilloba: Arxiu de Protocols del Reial Col-legi-Seminari de Corpus Christi de València (APCCV), reg. 27,371 (28-III-1477), quoted by Hinojosa Montalvo, 1999-2002; Sogorb: Arxiu de la Catedral de Sogorb (AHS), prot. 718, v. 8 (18-III-1499), quoted by Aparici Martí, 1998, p. 36; Llombai: AHN, Sección Osuna, Leg. 588/2 (1539), quoted by Gozálbez Esteve, 2006, p. 106.

6 AHN, OO.MM, Montesa, Carp. 520, n. 436-P (1285), published in Febrer Romaguera, 1991, p. 148-151

7 Archives Départementales du Var (ADV), Notarial, Brignoles, 3E7/147, s.f. (19-VIII-1434). The zone, rich with cork and chestnut trees, was during the fifteenth century an important producer of honey, that was sent off to Genoa, Naples and even Tunis via the port of Marseille. See some examples in Archives Départementales du Bouches du Rhône (ADBR), Notarial, 351/E323, s.f. (21-IX-1449), Archivio del Comune di Genova (ACG), ms. 272, Libro di Battista de Luco, f. 7v (11-II-1473) and also Rambert, 19491956, v. 3, p. 433. 
additional protection (Boudinot, 2010-2011, pp. 33-37). ${ }^{8}$ The Portuguese walled malhadas de abelhas suggest a common pattern of placement, usually at the bottom of ravines and near water streams (Henriques et al., 1999-2000; Lopes Pereira, 2009, p. 449). The estate accounts of Prussian Seehesten (now Szestno, Poland) suggests a more dispersed approach, with references to hives in trees around the castle wall, in nearby villages, and in the 'wilderness' (Franzke and Sarnowsky, 2015, pp. 106, 282). Tree beekeeping took place alongside domestic apiculture in beehives in this region, and both types of beekeeping could be land extensive-in 1434, the local convent at Graudenz had 85 hives 'on the heath', only 32 of which were occupied (Ziesemer, 1921, p. 604). What constituted heathland remains unclear, but may have varied from place to place and included stretches of forest, dwarf and subshrub or more developed shrubland and meadows (Jäger, 1999, pp. 89-90). The close proximity of urban centres and, especially, of suburban orchards-with which apiculture was generally at odds-was a matter of frequent regulation, and could result in banning it, limiting the number of hives held, or even restricting the activity temporarily so that it would not coincide with cereal harvesting and the vintage (Carreras Candi, 1923-1924, p. 396; Anyó Garcia, 1997, p. 64; Guinot Rodríguez, 2006, p. 392).

The siting of beehives was not permanent and could be moved to avoid unforgiving environmental changes. In Iberia, for example, a cold spring or an excess of fog fostered the transfer of beehives. In Aragón it was said that one had to shift hives at least half a legua $(2.8 \mathrm{~km}$.) in order for bees not to fly back to their original placement (Gil, 1621, f. 11r-11v, 199r-200r). Periodic conflicts with crops or vineyards could also stimulate the placement of hives in different settings in a given zone, while long range transhumance to overcome wintry conditions was also undertaken. ${ }^{9}$ An illustrative example is documented in the early fourteenth century, when groups of Valencian moors from Bunyol and Montserrat came into conflict with the local council of Requena, in neighboring Castile. ${ }^{10}$ These Muslims transited periodically with their hives carried by mules to take advantage of the late blossoming in Castilian Utiel, but were harassed by the local population, who seized their belongings and emptied and burned the hives.

The equipment required to tend to bees and extract produce similarly varied according to region, reflecting differences in hives and apicultural practice. Several

8 In 1341 Montmell (Catalonia), the perimeter was enforced in 9.3 meters. See Sans i Travé and Guasch Dalmau, 1979, p. 228.

9 For later periods, see Lemeunier, 2006 and Vila, 2003.

10 Conflicts are documented in 1306, 1307, 1308 and 1313. See ACA, Reial Cancelleria, reg. 139 Valencia, f. 86v-87r (28-XI-1306); Reg. 141, f.126r (11-XII-1307); Reg. 141, f.190r (6-II-1308); Reg. 152, f.281v (5-III-1313). There are roughly $75 \mathrm{~km}$. by road from Montserrat to Requena. Another transhumance route took place in the fifteenth century between the Aragonese Matarranya and La Plana, in Valencia. (Laliena et ali., 2016, p. 192-194) These same routes between inner Valencia and the coastal planes were still in use in the mid-twentieth century (Segrelles Serrano, 1989). 
specialised tools were used to harvest honey and wax in Iberia, southern France, and Italy, including a large spoon-shaped tool that was watered so honey could easily slide into it. (Alonso de Herrera, 1546, f. 149r) Removing honey in such a way could serve as a provisional measure to allow new space for production, but slicing off combs required longer knives, as depicted in the Exultet rolls of southern Italy (Gil, 1621, f. 91r, 102r; Mane, 1992, p. 1100). Some hives required even more specialist equipment: in the case of hives made from wooden frames, the latter had to be removed with what was described as a tempanador in Spanish, perhaps a sort of chisel. Nonetheless, sources are generally less specific on the equipment, and refer to broader 'utensils' (utensilios) in Castile, or simply to the 'equipment' (gescheide) required for beekeeping in Central Europe. ${ }^{11}$ In the latter region this also might have included axes and saws for pruning and felling trees (Schnelbögl, 1973, p. 132). The fact that so much of the apiculture around Nuremberg and along the Baltic littoral was based in trees often placed hives out of hand's reach, meaning that a pole-like implement-described in one Prussian charter of 1380 as una corda-was needed to attend to bee colonies often several metres high off the ground (Woelky and Saage, 1874, p. 87; discussed in Dombrowski, 1891, p. 96-7). Equipment for processing honey and wax did not fundamentally differ. Pots and vessels used for smelting wax can be found in diverse household inventories in the western Mediterranean during the late middle ages and appear in estate inventories of Prussian religious houses (d'Agnel, 1910, p. 248; Ziesemer, 1921, p. 94; Coulet, 1991, p. 13).

Yields provided by hives could vary considerably according to the location, climate, hive type, and management. The warmer climatic conditions in the Mediterranean made possible two full harvests a year, the first in late spring, and the second citra exitum mensis septembris according to the 1254 Statutum Massariarum of King Manfred of Sicily (Filangieri, 1980, p. 149). Yields in the Mediterranean varied greatly, but figures provided by modern research and historical treatises suggest that one hive could generally produce around 3.5 litres of honey and probably no more than $1 \mathrm{~kg}$. of wax each season (Naso, 1989, p. 209; Larguier, 1996, p. 124; Jaime Gómez and Jaime Lorén, 2002, p. 54). The colder conditions in Central Europe and along the Baltic littoral meant more infrequent harvests. Estimates for the productive capacity of Central European forests similarly vary, but Jäger has suggested that a medieval hive in spruce woodland could produce anywhere from 5.5 to 10 litres of honey per year. Estimates aside, the productive capacity of estates and individual beekeepers could be impressive, whatever the region (Jäger, 1991, p.

11 One man from the town of Cadalso, in Castile, was obliged in 1494 to pay the "fair price" for an apiary, its produce (castración) and utensils (utensilios) to a Jew that had sold him these elements before hastily fleeing the Kingdom in 1492. Archivo General de Simancas (AGS), Registro General del Sello (SGR), XI, $n^{\circ} 4188$, f. 269 (4-XII-1494). 
91). The Commander of Osterode (now Ostróda, Poland), a key commandery and fortress of the Teutonic Order that guarded the eastern flank of Prussia, recorded in 1392 no less than 28,000 kg. of honey in their cellar (Jäger, 1991, p. 92). Muchif not all-of this must have come from local production, and given Osterode's military importance, it may have been stockpiled over several years for victualling and medical purposes. Even a smaller estate, such as Seehesten, collected 3 tuns of honey in tax yearly and in 1451 purchased a further 18 tuns from local beekeepers, gathering also 64.25 pounds of wax in the same year from tithes and customary payments (Franzke and Sarnowsky, 2015, pp. 106-7; 110). More modestly, in the Mediterranean, the monastery of Roca Rossa, in Maçanet de la Selva (Catalonia) kept at least 24 hives belonging to the viscount Bernat de Cabrera in 1338, that could have produced approximately 84 litres of honey and $24 \mathrm{~kg}$. of wax per year, whilst two centuries later (1530-1534) the demesne of the monastery of Valldigna (Valencia) yielded between 22.5 and 119 litres of honey and 19 and $27 \mathrm{~kg}$. of wax per year ${ }^{12}$. This is in contrast with the 120 hives owned by one single agricultor, Joan Ona, from Xerta, in the Catalan lower Ebro, of which he could have harvested 420 litres of honey and $120 \mathrm{~kg}$. of wax in $1447^{13}$. The latter produce was purchased by a merchant from Tortosa, where the local product was mostly shipped to the main consumption centres of the Crown of Aragon. Tortosa was the entrepot for at least 4,296 litres of honey produced in its region and sent to the city of Valencia in $1488^{14}$. It is unsurprising that arguments over the rights to bee produce inflamed tensions in communities across Europe, for the honeyed rewards accruing to those with the rights to bee produce were significant.

Extracting honey and wax from hives was but one aspect of hive management, for beekeepers also needed to manage colony size and health and ensure that new swarms had somewhere nearby to establish themselves when they developed. Standard contracts ad meiriam in Provence depicted an individual owner renting for a limited period of time a number of brusquis sive alveis meis plenos et abelhats (my swarmed hives) to a holder, who was to guard and manage them, and who also received a number of empty cork hives into which to divert the swarms leaving their original hives. ${ }^{15}$ The forest law of Auerbach (Saxony, Germany) similarly foresaw issues arising from swarming, stipulating that beekeepers had the right to split hives as they saw fit and prepare up to six trees in each plot of forest for new colonies (Schnelbögl, 1973, p. 132). Here the forest law also sought to protect valuable

12 See Archivo Ducal de Medinaceli (ADM), Fondo Cabrera, Rt 0986, foto. 0516-0519, doc. 3730 (28-II1338) and Aparisi Romero, 2015, p. 113.

13 Arxiu Comarcal del Baix Ebre (ACBE), Notarial de Tortosa, sig. 54, f. 19v (2-II-1447). We thank Agustí Campos for this reference.

14 ARV, Batllia, Reg. 12.195.

15 ADV, Notarial, Brignoles, 3E7/147, s.f. (19-VIII-1434). 
bee trees from destruction that could come through other uses of the woodland, forbidding any individual from growing hops, installing hutches, erecting bathing huts, or stabling horses, without permission.

Bees were also vulnerable to changes in environment and climatic conditions, and disputes could arise when they died. New agreements regarding the division of hives' produce had to be reached between landlord and tenant in Provence were the colonies to perish, while rental agreements in Prussia and land grants in Greater Poland occasionally stipulated what should happen to the wax and honey of dead bees and absolved tenants of any guilt if bees died ${ }^{16}$. In 1291, for example, Duke Przemysł II of Poland granted a village near Poznań to a certain 'Henry', absolving him of all legal charges if the bees 'in the forests of the same village' were to perish on account of 'improving' them or renting them out (per melioracionem et locacionem). (Zakrzewski and Piekosinski, 1878, no. 672) This aside in an otherwise formulaic document suggests that in Greater Poland renting out the rights to hunt for honey in forests may have been commonplace, and that some party was legally liable if bees were to die- a situation the aforementioned Henry was keen to avoid. Fiscal powers were clearly well aware of the fragility of bees and the environments in which they subsisted. In 1521, ordinances of the income tax of Ullà, in Catalonia, by which $1 \mathrm{~d}$. was levied for the possession of every hive, established that the assessment should only be done after the month of March, to ensure only the bees which had survived the winter were taxed: fins sia passat lo mes de mars, si vives seran (until March has gone by, if they are alive). ${ }^{17}$ Evidence from other regions preserve more material shedding light on the management and ownership of hives and the disputes and disagreements that could emerge.

\section{MANAGEMENT AND OWNERSHIP}

The rights to install hives and to extract the valuable produce from within were often strictly regulated, but such regulation could take diverse forms. The interest of lords in hives on land to which they had rights in the Baltic littoral and Franconia has bequeathed a wealth of charter and account material that shed light on the more regulated and institutionalized beekeeping on estates and manors, whereas the notarial records of southern Europe preserve greater evidence of lower-level, domestic beekeeping, often undertaken by peasants through sharecropping agreements or by direct management.

The regulation of hive ownership and access to bee produce within Prussia underlines the variety of regulatory frameworks that could exist not just in a

16 Cases in Provence are tracked in: ADV, Notarial, Brignoles, 3E7/147, s.f. (19-VIII-1434 and 26-VIII-1434); Notarial, Tourves, 3E15/5, s.f. (4-V-1441).

17 Arxiu Històric de Girona (AHG), Notarial, Ullà, 226, f. 56r (13-VII-1522). 
region, but within a single estate. In Seehesten, an estate of the Teutonic Order in Prussia, two forms of law-Prussian, for natives, and Culm, for German settlers and their descendants-applied to apiculture, as it did to many forms of agricultural landholding. The bees around the castle wall were qualified as 'my bees and oak trees' by the estate official and were probably owned by him in the corporate sense that they were the property of the estate he led, but elsewhere in the estate's possessions things were more complicated. The official noted that he had the right to the honey produced by the beekeepers in three named surrounding villages and in the 'wilderness' because they were held according to Prussian Law, but the hives in Seeheesten itself were held according to Culm Law, meaning he had no right over them (Franze and Sarnowsky, 2015, p. 53). Elsewhere in Prussia matters were different again. The bishop of Ermland had his own hives at his residence of Bischoffsburg (now Biskupiec, Poland), for a complaint brief in 1414 noted how a Polish raid had destroyed 'all the hives of the bishop [kept] for honey with their bees' in the settlement, but the bishop also retained rights over subsequent bee produce on estates he sold or donated. In 1388, for example, the bishop freed a parcel of land of all labour obligations on the condition that the new owner attend to the beehives, reserving for the bishop one third of the honey harvested from the heath and one half from the garden (Woelky and Saage, 1874, pp. 506, 183). He went on to stipulate that the land could only be sold on to another if the new owner took responsibility for the hives, and that he would have the right to purchase up to one third of the honey from the garden at 2.5 marks a ton. The estates administered by the bishop's cathedral chapter in Frauenburg (now Frombork, Poland) on the Vistula lagoon exhibit similar diversity. In 1447, for example, the chapter stipulated that in their estate of Allenstein the beekeepers were to be freed of all labour services and to keep all honey from both old and new hives, although they were not allowed to hollow out more than thirty trees for new hives per year. Any wax taken from the hives from dead bees, furthermore, was reserved for the beekeeper's use, suggesting that this was usually not the case (Thimm, 1969, p. 125). We can only guess at how these regulations played out in practice, but if Seehesten's accounts for 1450-2 are a reliable indicator, the quotidian issues raised by keeping bees and interpreting rights to their produce and sale could degenerate into confusion and recrimination: five named locals were labelled 'honey robbers', having stolen from the estate's bees and oak trees, while the men who attended the 'hives in the wilderness' allegedly unlawfully withheld the wax they owed to the estate (Franzke and Sarnowsky, 2015, pp. 53, 106, 282).

In southern Europe, the legal regulation of the ownership of hives was not as variable as in the north. Ius commune and its derived local charters and ordinances regulated the possession of beehives as well as their loss and theft (Ortega Gil, 1995, pp. 48-49). In general, local bylaws granted sufficient space between hives 
or apiaries for bees to forage and prescribed the places where the hives could be installed. Conflicts could arise in relation to the use of woods and wasteland for beekeeping, namely when privatized by territorial lords (Farías, 2011, pp. 71-75). Nonetheless, the importance of revenues from taxation on both hive possession and trade in their produce, could have also eased the regulation of wild swarmcapturing. The ordinances granted by the bishop of Barcelona in his domain of Montmell (Catalonia) allowed anyone to take possession of any wild hive that was found (Sans i Travé and Guasch Dalmau, 1979, p. 236).

In southern Europe, bee products appear frequently in rental agreements, although the rents collected from peasants by lords were more often in wax than honey. To take one illustrative case, in 1379 a certain Calvagnu di Busmenzu from Monreale, in Sicily, owed a rotulo (750 gr.) of wax to the nearby monastery of San Martino delle Scale for holding a vineyard, suggesting beekeeping was significant in the region (Rinaldi, 1989, p. 374). Recognition of serfdom and customary payments, where these social institutions existed, could also count on regular remittance of wax. One Pere Cabeça and his wife from Lloret (Girona) recognized the knight Berenguer de Cartellà as their only lord, owing him personal dependence, and obliging themselves to a fixed yearly fee of 600 gr. of wax whilst another couple from Gravelos, in Portugal, had received a landholding from King Afonso III in 1258 for which they accepted an array of banalités which were owed in wax. ${ }^{18}$ In Prussia, tenants of the Teutonic Order often paid nominal rents in wax in recognition of the latter's authority (Laczny, 2019, p. 147).

Not all beekeeping took place as an ancillary activity to other pursuits, and specialized beekeepers also appear in the records. Beekeeping certainly needed specific expertise, acquired only through practice. One had to keep track of the size of the swarm, ensure it was well fed, the hive was clean, and that bees were in good health and free from predators. In certain regions, partial extraction of honey was also to be done periodically during the months of more intense activity (Gil, 1621, f. 153v). Specialization could arise from specific entitlement granted by public powers. The royal demesne in Sicily employed a specialist beekeeper as early as the thirteenth century (Naso, 1989, p. 208), and the King of France and other territorial lords one century later enabled special officers (bigres) in Normandy authorized to capture wild swarms (Decq, 1922, p. 109; Plaisse, 1966, pp. 12-13) while the bishop of Ermland referred to 'our beekeepers' in land grants in the fourteenth and fifteenth centuries. (Dombrowski, 1891, pp. 84-5) Zeydeler (or variants, such as zeydler/zeidler), specialised practitioners of apiary in the forests of Franconia, are referred to as early as the tenth century. Lists of 'Zeidlers' swearing oaths survive in Nuremberg city council's records from as early as 1310, and 'The Zeidler oath'

18 See AHG, Notarials, Caldes-Llagostera, 22, f. 21v (12.1.1342) and ANTT, Chancelaria de D. Afonso III, Liv. I (4-IV-1258). 
(der zeÿdler ayde) sworn before Nuremberg's city council survives in a fifteenthcentury codex under the date of 1429 , offering a contemporary perspective on the landscape and vegetation that beekeepers and their overseers held to be important and that needed protecting. (Bischoff, 1956, pp. 48-9) The fact that the 'Zeidler' swore not to do anything 'damaging to the forest' (dem wald schedlichen) in general, nor anything that could damage linden (linden) and shrubbery (spurkeln an salhen) 'on the heath and hive trees' (an der heide und an peuten pawm), highlights the overriding importance of woodlands and their hinterlands of heath in supporting bee colonies. ${ }^{19}$ Elsewhere in Franconia, records from the later 1300s state that for each 'Zeidel' pasture held at Auerbach the 'Zeidler' was to render a measure of honey to the lord and one shilling in cash, while an estate book for nearby Cadolzburg in 1414 recorded two individuals holding 'Zeidel' pasture, who rendered half their wax and honey yearly to their lord (Bischoff, 1956, pp. 84-5). It is important to emphasise, however, that beekeeping in the manner of Zeidlerei was probably widespread throughout German-speaking lands and central and eastern Europe, but has been obscured by poor source survival or different terminology. Furthermore, although this type of specialized beekeeper is well-known for the area around Nuremberg, it is clear that professional beekeepers were found throughout Europe. And peasants, too, could specialize in beekeeping. To give but one example, when the peasant Francesc Seder of Ribesaltes (Roussillon) was for reasons unknown to us sent to the royal gaol, he claimed that he kept a certain number of beehives and that during his absence in the month of March there would not be anyone skilled enough to manage them: "per no aver persona qui entena lo regiment ni sia pràtic en lo govern de dits buchs de abellas". ${ }^{20}$

Professional beekeeping coexisted with domestic production, but the very fact that low-level apiculture was often undertaken alongside other occupations means that its existence can be difficult to recover. An inventory drafted after the death of the shoemaker Antoni Taverner, in 1472 Sant Feliu de Guíxols (Catalonia), proved that he ended his days fully active, since a total of 43 new pairs of shoes were found in his house. ${ }^{21}$ The same document went on to record that he kept four beehives in the entrance of his home and another in an orchard nearby, where he also guarded three chickens and grew flax, beans and cabbage. Not surprisingly, in different chambers inside his house, ten different containers with honey, $23 \mathrm{~kg}$. of wax, and also one somada of cork (presumably, to build or fix beehives) were found. In this sense, beehives were sold, endowed and bequeathed as any other chattel, and notarial evidence for which is innumerable in regions wherever ledgers have been preserved. Sixty-four empty and inhabited hives were inherited by the heirs of a man

19 Staatsarchiv Nürnberg, Rep 52c, $5 \mathrm{a}$.

20 Archives Départementales des Pyrénées-Orientales (ADPO), Notarial, B377, s.f. (14-III-1581).

21 AHG, Notarial, Sant Feliu de Guíxols, 1055, s.f. (22-I-1472). 
from the castle of Masaugas (Provence) in 1441, while in 1465 Vidreres (Catalonia) another man identified as an agricultor acknowledged a payment from his neighbour for a temporary sale of two sets of hives located in a forest and by a stream. ${ }^{22}$

Moveable hives with their precious wax and honey within were understandably tempting to robbers, especially as they were left alone for long periods in isolated meadows and forest. Either because it had taken place in the royal domain, or due to its significant value, numerous cases related to theft of either hives or the produce itself ended up in the higher chambers of justice, and were dealt with severely: in 1435 a man from Portimão (Portugual) was imprisoned and then expelled from the city for having stolen and emptied (escorchar) hives, although he was later acquitted of this felony, while Joao Gomes Alvela from Alcanede was ostracized to Ceuta in 1445 for having robbed his own father a certain amount of hives, along with bread and wine. ${ }^{23}$ As seen, in the Mediterranean it was usually the ordinary justice, either royal or seignorial, that dealt with theft of hives (Garcia-Oliver, 2003, pp. 62-63; Bresc, 2010, p. 20). But to prevent burglary and enforce the norms imposed on beekeeping by the ordinances, such as placement of hives and distances between apiaries, in some regions in the Kingdom of Castile, local powers enabled a jurisdictional officer (the alcalde de colmeneros) to take charge (Bordons Alba and Pérez Carrera, 1995, pp. 152-153) while in the forests around Nuremberg matters related to beekeeping were settled in the 'Zeidler' court at Feucht (Bischoff, 1956, pp. 55-6). Hives lodged in sturdy trees could also be subject to criminal damage. The forest law of Auerbach prescribed a fine in cash for any who cut down a tree capable of bearing bees, while cutting down a tree bearing a hive incurred the penalty of having your hand removed (Schnelbögl, 1973, p. 132). Such legislation can be seen elsewhere in Central Europe: King Casimir the Great of Poland's ordinance of 1357, for example, made official what was perhaps already customary, prescribing punishments for anyone who chopped down trees with bees or trees that had been adapted-hollowed out, one presumes—for bees. (Ferenc-Szydełko, 1995, p. 10)

\section{CONCLUSIONS}

The foregoing has discussed an important division of beekeeping types in northern and southern Europe: the land-extensive tree beekeeping of the north and east, and the more resource-intensive hive beekeeping of the south and west. This was due to the broad environmental differences between the two zones in terms of climate, vegetation and topography on the one hand, and in population and settlement structure on the other. It has in particular been seen that the strict jurisdictional

22 ADV, Notarial, Tourves, 3E15/5, s.f. (27-IX-1441); AHG, Notarial, Vidreres, 76, s.f. (7-XI-1465).

23 See ANTT, Chancelaria de D. Duarte, Liv. 3 (26-IV-1435) and Chancelaria de D. Alfonso V, Liv. 5, f. 78 (14-IX-1446). 
rights of territorial lords in Prussia, Livonia and Franconia, led to the development of a legal framework-or sets of overlapping frameworks-in which use of forest resources were strictly regulated because they were so closely aligned with seigneurial privilege. This explains the abundance of estate surveys and charters from these regions which preference explanation of the lords' rights over lands and their produce, over the small-scale production of peasants on their own lands or when such production did not come into conflict with the lord. Comparison of the image of beekeeping which emerges from these documents with the extensive private notarial evidence for the south can provide something of a false impression, by which in the former region lord-controlled beekeeping and demesne production abounded, while in the latter, petty peasant production was the norm.

To study beekeeping is to study a natural resource, a product that, although originally provided by the ecological context, was modified and utilized to meet a specific social demand (Boisseuil and Bernardi, 2007). In this, it is not only the environmental setting which needs to be taken into account, but also those cultural elements that permitted its appropriation, extraction and transformation in which the important ecological impact of beekeeping, the technical and legal solutions that surrounded it, and even its social and cultural outcomes have been highlighted. In other words, the cultural landscape in which it was embedded, and by which it was shaped.

Rather than existing naturally, overlaid on top of other activities but not interacting with them, beekeeping was the product of much human intervention in the landscape, competing with other types of resource use from a variety of actors. In places where beekeeping took place in forests, it was crucial to curtail extraction of undergrowth and the destruction of trees-here demand for timber, firewood and charcoal diminished bee forage and impinged upon delicate bee habitats. Where beekeeping took place in hives, skeps and logs, the relatively greater population density and difference in vegetation and land uses, in particular of arable agriculture, viticulture and pastoralism, in addition to the inherent mobility of these types of hives, meant that their placement was often strictly regulated, with limits on where they could be put, and sometimes even involving seasonal movement of hives-in addition to the transhumance necessary to find forage over the year. Where pastoralism made extensive use of fire, as in much of the Mediterranean basin, the beehives could easily be destroyed, although the frequent fires also enhanced the growth of bee forage. Additionally, a profusion of agricultural treatises provide evidence of the selection of particular plants and trees, suggesting that vegetation well-suited to beekeeping could specifically be chosen for this purpose-by the early sixteenth century, for example, the Castilian Gabriel Alonso de Herrera warned beekeepers about the scarcity of suitable pastos $y$ flores and recommended the planting of particular species, an aspect of resource allocation which no doubt further contributed to the anthropization of the landscape (Alonso de Herrera, 1546, f. 140v). 
By the later middle ages, it is clear that beekeeping was an important component of land and estate management, as demonstrated by the emergence of a set of jurisdictional bodies specifically devoted to the enforcement of the rules applying to this activity, a clear sign of the social and economic strength of this sector and the rights which were attached to it. The social status of specialized beekeepers in this period is similarly indicative of this. Yet the existence of such courts suggests that in certain contexts beekeeping was particularly likely to come into conflict with other activities, and so required close regulation. This likely increases as land use became more intense over time. It is unfortunately not possible from the sources here to assess change in the number of hives across Europe over time. However, it can be suggested that demand for bee products increased over the course of the period surveyed, due to growing population and consequent demand for goods of all types, including wax and honey. Demand for wax especially increased over the later middle ages with the proliferation of Christian religious services and increasing emphasis on feasts related to Christ and Mary, which often centred on large-scale consumption of wax candles, and this was likely further enhanced by the increase in living standards seen in many places after the Black Death, which allowed more money to be spent on religious observance (Sapoznik, 2019, p. 1154). In this, it is likely that in regions where large-scale beekeeping was practiced, there was also increasing specialisation-although alongside the proliferation of small-scale operations.

The centrality of beekeeping in the middle ages is also demonstrated through the changing cultural approaches to it. Skills and tools, including hive types, varied throughout the two zones under consideration here, depending not only on the materials available, but also on cultural patterns. The imperial dimension and patronage of the Zeidler-type apiculture in and around Nuremberg until 1427, when the royal forest was sold to the city, has lent the region a special status, reflected in the historiography since the nineteenth century. At the same time, medieval men and women, even from urban areas or the nobility, were also familiar with the life of bees and apiculture. In this context, historians have stressed the profusion of metaphors and linguistic resources borrowed from bees in the late middle ages (Prosperi, 2010, pp. 145-210). Thus, it does not pass unnoted that when Queen Mary of Aragon decided in 1435 to address her General Parliament in Monzón, she urged the different representatives of the Kingdom to 'imitate the bees' who, according to 'authentic writings', acted with 'concord, unity and diligence' in producing the comb. ${ }^{24}$ Thus it can be seen that bees were small insects with large consequences.

24 ACA, Cancelleria Reial, reg. 33, f. 125r (20-III-1346). 


\section{REFERENCES}

D’Agnel, G.A. (Ed.) (1910). Les comptes du Roi René. Vol. 1. Paris: A. Picart et Fils. Agustí, M. (1617). Llibre dels secrets de agricultura, casa rústica y pastoril. Barcelona: Esteve Liberós.

Alonso de Herrera, G. (1546). Libro de agricultura que es de labrança y criança y de muchas otras particularidades y prouechos de las cosas del campo copilado por Gabriel Alonso de Herrera. Toledo: Fernando de Santa Catalina.

ANYÓ GARCiA, V. (Ed.) (1997). El primer manual de consells de la ciutat de València. Valencia: Ajuntament de València.

ApARICI MARTí, J. (1988). De la apicultura a la obtención de la cera. Las "otras manufacturas" medievales de Segorbe y Castelló. Millars. Espai i Història, (21), 31-50.

APARISI ROMERO, F. (2015). Del camp a la ciutat. Les elits rurals valencianes a la Baixa Edat Mitjana. Unpunblished PhD Thesis. Valencia: Universitat de València.

ApArisi Romero, F. (2021). L'apicultura a la València medieval. In E. Vicedo (Ed.), Cultius, especialització i mercats. Lleida: Institut d'Estudis Ilerdencs.

Bischoff, J. (1956). Die Zeidelhuben und Bienenpflege im Sebalder Reichswald zwischen Erlangen und Nürnberg in siedlungs- und waldgeschichtler Sicht. Jahrbuch für fränkische Landesforschung, (16), 29-107.

Boisseuil, P. and Bernardi, P. (2007). Des «prouffitz champestres» à la gestion des ressources naturelles. Médiévales, (53), 5-10. https://doi.org/10.4000/medievales.3173

Bordons Alba, C. and Pérez Carrera, F. M. (1995). El concejo de Sevilla, de Nicolás Tenorio Cerero estudio, edición e índices. Seville: Universidad de Sevilla.

BoudinOt, L. (2010-2011). Lapiculture à La Garde-Freinet et dans le massif des Maures de la fin du XVI ${ }^{e}$ siècle au milieu du XVIII ${ }^{e}$ siècle. Freinet-Pays des Maures, (9), 31-86.

BRESC, H. (2010). Justice et société dans les domaines de l'évêque de Fréjus dans la première moitié du XIVe siècle. In J.-P. Boyer and T. Pécout (Dir.), La Provence et Fréjus sous la première maison d'Anjou. Toulouse: Presses universitaires de Provence. VON Bunge, F.G. (Ed.) (1968). Liv-, Est- und Kurländisches Urkundenbuch nebst Regesten: Abteilung 1 Band 2, 1301-1367. Aalen: Scientia Verlag.

BURRI, S. (2016). Essartage, culture temporaire et habitat en Basse-Provence entre Moyen Âge et première modernité ( $\mathrm{xiii}^{\mathrm{e}}-\mathrm{xvi}^{\mathrm{e}}$ siècles). Histoire et Sociétés Rurales, (46/2), 31-68. https://doi.org/10.3917/hsr.046.0031

Cabezuelo, J.V. (2019). Señorío, frontera y expansión agrícola en el sur del reino de Valencia. El linaje Vilanova en la primera mitad del siglo XIV. Imago Temporis. Medium Aevum, (13), 396-429.

CAnova, G. (1999). Api e miele tra sapere empirico, tradizione e conoscenza scientifica nel mondo arabo-islamico. In G. Canova (ed). Scienza e Islam (pp. 69-92). Rome: Herder. 
Carmona Ruiz, Ma. A. (1999). La apicultura sevillana a fines de la Edad Media. Revista española de estudios agrosociales y pesqueros, (185) 131-154.

CARRERAS CANDI, F. (1923-1924). Ordinacions urbanes de bon govern a Catalunya (Segles XIII a XVIII). Ordinacions o establiments de Tortosa (anys 1340-1344). Boletín de la Real Academia de Buenas Letras de Barcelona, (11), 365-431.

Coulet, N. (1991). L'équipement de la cuisine à Aix-en-Provence au XVe siècle. Annales du Midi, (103/193), 5-17. https://doi.org/10.3406/anami.1991.2280

Crane, E. (1999). The World History of Beekeeping and Honey Hunting. London: Duckworth. https://doi.org/10.4324/9780203819937

DE CRESCENZI, P. (1474). Liber commodorum ruralium. Lovaine: Jean de Westphalie. DECQ, E. (1922). Ladministration des eaux et forêts dans le domaine royal en France aux XIVe et XVe siècles. Bibliothèque de l'École des chartes, (83), 65-110. https://doi.org/10.3406/bec.1922.448672 https://doi.org/10.3406/bec.1922.448671

DEVY-VARETA, N. (1985). Para uma geografia histórica da floresta portuguesa. Revista da Facultade de Letras - Geografia, (1), 5-37.

Dombrowski, E. (1891). Die mittelalterliche Bienenwirtschaft im Ermlande. Zeitschrift für die Geschichte und Alterthumskunde Ermlands, (27-29), 83-110.

DuARTE, L. M. (1999). Sarilhos no campo. In M. J. Barroca (Ed.). Carlos Alberto Ferreira de Almeida: in memoriam (Volumen I) (pp. 299-314). Oporto: Faculdade de Letras da Universidade do Porto.

FARÍAS, V. (2011). El mas i la vila a la Catalunya medieval: Els fonaments d'una societat senyorialitzada (segles XI-XIV). València: Publicacions de la Universitat de València.

Febrer Romaguera, M. V. (1988). La organización judicial de las aljamas mudéjares valencianas y la Suna e Xara. In XVI Asamblea de Cronistas Oficiales del País Valencià (pp. 193-217). València: Acadèmia de Cultura Valenciana.

Febrer Romaguera, M. V. (Ed.) (1991). Cartas pueblas de las morerías valencianas y documentación complementaria. Zaragoza: Anubar.

FERENC-SZYDEŁKO, E. (1995). Organizacja I funkcjonowanie bartnictwa $w$ dobrach monarszych w Polsce. Pozna: wydawnictwo pozna skiego towarzystwa przyjació nauk.

FerRer i MALlol, M. T. (1986). La carta de població dels sarraïns de la vall d'Aiora (1328). Sharq Al-Andalus, (3), 81-94. https://doi.org/10.14198/ShAnd.1986.3.08

Filangeri, R. (Ed.) (1980). I registri della Cancelleria Angiona. Vol. 31. Naples: Academia Pontaniana.

FranzKe, C.A. and Sarnowsky, J. (Ed.) (2015). Amtsbücher des Deutschen Ordens um 1450. Pflegeamt zu Seehesten und Vogtei zu Leipe. Göttingen: Vandenhoeck \& Ruprect. https://doi.org/10.14220/9783737003582

Ganau, J. (Ed.) (1996). Viatges per Ponent. Lleida: Edicions de la Universitat de Lleida. 
García García, H. (1948). Rendición del castillo de Xivert. Boletín de la Sociedad Castellonense de Cultura, 26, 231-233.

GARCIA-Oliver, F. (2003). La vall de les sis mesquites. El treball i la vida a la Valldigna medieval. Valencia: Publicacions de la Universitat de València.

GIL, J. (1621). Perfecta y curiosa declaración de los provechos grandes que dan las colmenas bien administradas y alabança a las abejas. Zaragoza: Pedro Gel.

GOZÁlbEZ Esteve, E. (2006). Rentas señoriales en el marquesado de Llombai (XVI-XVII). Revista de Historia Moderna, (24), 67-122. https://doi.org/10.14198/ RHM2006.24.03

Gual Camarena, M. (1989). Las Cartas Pueblas del Reino de Valencia. Valencia: Desamparados Pérez Pérez.

Guinot Rodríguez, E. (1986). El señorío de la Vall de Perputxent (siglos XIII-XIV). Anales de la Universidad de Alicante: Historia Medieval, (4-5), 99-118. https://doi. org/10.14198/medieval.1986.4-5.04

GUINOT RodRíGUEZ, E. (Ed.) (1991). Les cartes de poblament medievals valencianes. Valencia: Generalitat Valenciana.

Guinot Rodríguez, E. (1992). El patrimoni reial al País Valencià a inicis del segle XV. Anuario de Estudios Medievales, (22), 581-639.

https://doi.org/10.3989/aem.1992.v22.1082

Guinot RodríGuez, E. (Ed.) (2006). Establiments municipals del Maestrat, els Ports de Morella i Llucena (segles XIV-XVIII). Valencia: Universitat de València.

HENRIQUES, F. et ali. (1999-2000). Muros-apiários da bacia do médio Tejo (regiões de Castelo Branco e Cáceres). Ibn Maruán, (9/10), 2-29.

Hinojosa Montalvo, J. (1999-2002). Ares y Benilloba (Alicante): Dos comunidades mudéjares valencianas a fines de la Edad Media. Sharq al-Andalus, (16-17), 45-71. https://doi.org/10.14198/ShAnd.1999-2002.16-17.04

Hinojosa Montalvo, J. (2008-2010). Ondara. Señorío del Duque de Gandía, a principios del siglo XV. Sharq al-Andalus, (19), 35-68. https://doi.org/10.14198/ ShAnd.2008-2010.19.02

Hinojosa Montalvo, J. (2020). El bosque y la leña en el reino de Valencia en los siglos medievales (XIII-XV). Estudios de Historia de España, (22/1), 1-19. https://doi.org/10.46553/EHE.22.1.2020.p1-19

JÄGER, H. (1999). Pflanzliche Ressourcen in mittelalterlichen und frühneuzeitlichen Kulturlandschaften. In R. Rolle and F. M. Andraschko (Ed.), Frühe Nutzung pflanzlicher Ressourcen: internationales Symposium Duderstadt, 12.-15.5.1994 (pp. 88-99). Hamburg: Lit.

JAime GómeZ, J. and JAime LorÉn, J.M. (2002). Historia de la Apicultura Española. Vol. 2. Calamocha.

KL̀AVIN̦Š, K. (2019). Reorganizing the Livonian Landscape: Some Issues and Research Perspectives. In A. Pluskowski (Ed.) Ecologies of Crusading, Colonization, and 
Religious Conversion in the Medieval Baltic. Terra Sacra II (pp. 197-211). Turnhout: Brepols.

LACZNY, J. (2019). Schuldenverwaltung und Tilgung der Forderungen der Söldner des Deutschen Ordens in Preußen nach dem Zweiten Thorner Frieden. Ordensfoliant 259 und 261, Zusatzmaterial. Göttingen: Vandenhoeck \& Ruprecht. https://doi. org/10.14220/9783737009423

Laliena Corbera, C. et ali. (2016). Transformaciones en la Baja Edad Media. El Matarraña, de la crisis a la expansión. In C. Laliena Corbera (coord.) Matarannya, gentes y paisajes en la Edad Media (pp. 150-295). Zaragoza: Gobierno de Aragón. LARGUiER, G. (1996). Le drap et le grain en Languedoc: Narbonne et Narbonnais, 13001789. Perpignan: Presses Universitaires de Perpignan.

LEMEUnier, G. (2004). Viajes de abejas. La trashumancia apícola en la Cataluña norte (s. XIX). In J. L. Castán Esteban and C. Serrano Lacarra (coord.), La trashumancia en la España mediterránea: historia, antropología, medio natural, desarrollo rural (pp. 387-404). Zaragoza, Centro de Estudios sobre Despoblación y Desarrollo de Áreas Rurales.

LEMEUNIER, G. (2006) La pratique européenne de la transhumance en apiculture traditionnelle (v. 1750-v. 1850). Les Cahiers d'Apistoria, (4), 17-26.

Lopes Pereira, M. T. (2009). O mel e a cera em Portugal na Idade Média Olhares sobre a História. In Maria do Rosário Themudo Barata and Luís Krus (Dir.) Olhares sobre a História. Estudos oferecidos a Iria Gonçalves (pp. 447-467). Lisboa: Caleidoscópio.

LOSERT, H., and WERTHER, L. (2010). Relikte einer spätmittelalterlichen Zeidlerei in der Oberpfalz. Siedlungsforschung: Archäologie - Geschichte - Geographie, (28), 215-35.

MANE, P. (1992). L'outil et le geste: iconographie de l'agriculture dans l'Occident médiéval (IXe-XVe siècles). Lille: Atelier National de Reproduction des Thèses.

MARTín GutiÉRreZ, E. (2011). Reflexiones en torno a los paisajes rurales bajomedievales. Algunos ejemplos andaluces. In Emilio Martín Gutiérrez (Ed.) El paisaje rural en Andalucía Occidental durante los siglos bajomedievales. Actas de las I Jornadas Internacionales sobre paisajes rurales en época medieval (pp. 31-52). Cádiz: Universidad de Cádiz.

NASO, I. (1989). Apicoltura, cera e miele. In Giosue Musca (Ed.) Uomo e ambiente nel Mezzogiorno normanno-svevo (pp. 203-240). Bari: Dedalo.

ORTEGA GIL, P. (1995). Hurtos de colmenas: Apuntes históricos. Cuadernos de Historia del Derecho (22), 45-71. https://doi.org/10.5209/rev_CUHD.2015.v22.50530

Pastor i MAdalena, M. (Ed.) (2004). El cartulari de Xestalgar: memòria escrita d'un senyoriu valencià. Barcelona: Fundació Noguera.

Plaisse, A. (1966). Les forêts de la Haute-Normandie à la fin du moyen âge. Études Normandes, (190), 1-23. https://doi.org/10.3406/etnor.1966.1303 
Pluskowski, A. (2019a). Environment, colonization, and the Baltic Crusader States. Terra Sacra I. Turnhout: Brepols.

PlusKOWSKI, A. (2019b). Introduction: Multi-Scalar Impacts of Crusading on the Environments of the Eastern Baltic. In A. Pluskowski (Ed.) Ecologies of Crusading, Colonization, and Religious Conversion in the Medieval Baltic. Terra Sacra II (pp. 1-14). Turnhout: Brepols.

Prosperi, L. (2010). Il miele nell'Occidente medievale. Firenze: Accademia dei Georgofili-Le Lettere.

RAMBERT, G. (Dir.) (1949-1956). Histoire du commerce de Marseille. Vol. 3. Marseille: Chambre de Commerce de Marseille.

RiERA, A. (2017). The beginnings of urban manufacturing and long distance trade.

In F. Sabaté (Ed.) The Crown of Aragon. A singular Mediterranean Empire (pp. 201236). Leiden-Boston: Brill. https://doi.org/10.1163/9789004349612_009

Rinaldi, G. M. (Ed.) (1989). Il “Caternu” dell'abate Angelo Senisio: l'amministrazione del Monastero di San Martino delle Scale dal 1371 al 1381. Palermo: Centro di studi filologici e linguistici siciliani.

SÁnCHEz BENito, J. M. (1989). Datos sobre la organización de la producción apícola castellana en la baja Edad Media. Estudis d'Història Econòmica, (1), 11-25.

Sans i Travé, J. and Guasch Dalmau, D. (1979). Les Ordinacions del Montmell (segle XV). Miscel-lània Penedesenca, (2), 221-246.

SCHNElbÖGL, F. (Ed.) (1973). Das “Böhmische Salbüchlein” Kaiser Karls IV. über die nördliche Oberpfalz 1366/68. Munich: R. Oldenbourg.

SEGRELLES SERRANO, J.A. (1989). La apicultura valenciana: un aprovechamiento agrario tradicional. Cuadernos de Geografía, (45), 73-88.

THIMM, W. (1969). Die Ordnungen der ermländischen Kapitelsburgen Allenstein und Mehlsack aus dem Jahre 1563. Ein Beitrag zur Geschichte des Herrschaftsgefüges im Hochstift Ermland. Zeitschrift für die Geschichte und Altertumskunde Ermlands, (94), 53-157.

Vila, Pau. (2003). Resum de geografia de Catalunya. Barcelona: Institut d'Estudis Catalans.

Villalmanzo Cameno, Jesús (1986). Mudéjares y cristianos en el señorío de Cheste (siglo XIV). Dos criterios de repoblación. Anales de la Universidad de Alicante: Historia Medieval, (4-5), 131-150. https://doi.org/10.14198/medieval.1986.4-5.06 WARnKe, C. (1987). Der Handel mit Wachs zwischen Ost- und Westeuropa im frühen und hohen Mittelalter. In K. Düwel, H. Jankuhn, H. Siems and D. Timple (Ed.), Untersuchungen zu Handel und Verkehr der vor- und frühgeschichtlichen Zeit in Mittel- und Nordeuropa: Teil IV - Der Handel der Karolinger- und Wikinger Zeit. (pp. 545-569). Göttingen: Vandenhoeck \& Ruprecht.

Woelky, C.P. and SAAGE, J.M. (Ed.) (1874). Codex Diplomaticus Warmiensis oder Regesten und Urkunden zur Geschichte Ermlands. Bd. 3: Urkunden der Jahre 13761424 nebst Nachträgen. Braunsberg: Eduard Peter. 
ZAKRZEWSKI, I. and PieKosinski, F. (Ed.) (1878). Codex Diplomaticus maioris Poloniae. Bd. 2: Comprehendit numeros 617-1292. Annos 1288-1349. Poznań: Edward Raczyski.

ZIESEMER, W. (Ed.) (1921). Das Große Ämterbuch des Deutschen Ordens. Gdańsk: Martin Sändig. 